\title{
The hydrography and biology of a bloom of the coccolithophorid Emiliania huxleyi in the northern North Sea
}

\author{
Robert N. Head ${ }^{\text {a,*}}$, David W. Crawford ${ }^{\text {b,1 }}$, Jorun K. Egge ${ }^{c}$, Roger P. Harris ${ }^{\text {a }}$, \\ Svein Kristiansen $^{\text {d, David J. Lesley }}{ }^{\mathrm{a}, 2}$, Emilio Marañón ${ }^{\mathrm{e}, \mathrm{b}}$, David Pond ${ }^{\mathrm{a}}$, Duncan A. Purdie ${ }^{\mathrm{b}}$ \\ ${ }^{a}$ Plymouth Marine Laboratory, Prospect Place, West Hoe, Plymouth, PL1 3DH, UK \\ ${ }^{b}$ Department of Oceanography, University of Southampton, Southampton Oceanography Centre, European Way, \\ Southampton, SO14 3ZH, UK \\ ${ }^{c}$ Department of Fisheries and Marine Biology, University of Bergen, Bergen High Technology Centre, N-5020, Bergen, Norway \\ ${ }^{d}$ Department of Biology, University of Oslo, P.O. Box 1069, Blindern, N-0316, Oslo, Norway \\ ${ }^{e}$ Unidad de Ecología, Departamento de Biología de Organismos y Sistemas, Universidad de Oviedo, E-33071, Oviedo, Spain
}

Received 18 April 1997; accepted 2 September 1997

\begin{abstract}
In June/July 1994 a study was made of a small bloom of the coccolithophorid Emiliania huxleyi in an area of the North Sea to the east of the Shetland Islands. Observations on the hydrography of the study area indicated the bloom was associated with Atlantic water and was confined to an area in which a stable shallow mixed layer had formed. There was no evidence to suggest association of horizontal physical structure with the bloom development. High cell densities of $>1-6 \times 10^{6}$ cells dm${ }^{-3}$, together with low concentrations of PIC $\left(<50 \mu \mathrm{g} \mathrm{dm}^{-3}\right)$ and detached liths $\left(2-3 \times 10^{4}\right.$ liths $\mathrm{cm}^{-3}$ ) indicated that the bloom was studied at an early stage of development. Biochemical and physiological observations indicated active growth was taking place. The results presented are discussed in comparison with previous studies carried out in both oceanic and shelf seas. () 1998 Elsevier Science B.V. All rights reserved.
\end{abstract}

Keywords: Emiliania huxleyi; calcification; coccolith; North Sea; photosynthesis

\section{Introduction}

Coccolithophores comprise one of the main groups of calcifying organisms in the marine environment. Emiliania huxleyi (Lohmann) Hay and

\footnotetext{
* Corresponding author. E-mail: rnh@wpo.nerc.ac.uk

${ }^{1}$ Present address: Department of Earth and Ocean Sciences (Oceanography), University of British Columbia, Vancouver, BC, V6T Z4, Canada.

${ }^{2}$ Present address: DERA Hasler, Environmental Sciences Department, SWA Systems Sector, Gosport, Hants., PO12 2AG, UK.
}

Mohler is the dominant coccolithophorid and this species has a worldwide distribution and forms extensive blooms in both coastal and open oceanic waters (Brown and Yoder, 1993; Holligan et al., 1993b; Westbroek et al., 1993; Heimdal et al., 1994). Coccolithophores may generate large oceanic blooms exceeding $100000 \mathrm{~km}^{2}$ in area (Brown and Yoder, 1994; Fernández et al., 1993). Coccolithophore blooms may persist for 3-6 weeks, can act as passive tracers of water movement, and have a variable distribution from year to year (Holligan et al., 1993b). In the North Sea, blooms of E. huxleyi develop each 
year in early summer (late May-August), as revealed by satellite imagery (Holligan et al., 1989, 1993b). The presence of E. huxleyi has been related to the inflow of Atlantic water into the North Sea (Holligan et al., 1993b) and some of the most extensive populations appear to the northeast of the Scottish mainland (Holligan et al., 1989, 1993b). The species also occurs annually in Norwegian coastal waters, as well as in the North Sea away from direct oceanic influences. A previous study of a bloom of E. huxleyi in the northern North Sea (Buitenhuis et al., 1996; Van der Wal et al., 1995), has shown that this bloom originated from low saline run-off from the Norwegian fjords.

A cruise was organised on RV 'Håkon Mosby' in June/July 1994 as part of the MAST-II EHUX programme (Harris, 1996). The aim of the cruise was to investigate blooms of E. huxleyi in the North Sea to make comparisons with results obtained from both mesocosm experiments (Egge and Heimdal, 1994) and investigations in Norwegian fjords (Kristiansen et al., 1994). The area studied was located in the North Sea east of the Shetland Islands, where coccolithophorid blooms have been observed in previous years using satellite imagery. The intention was to direct the vessel to a bloom of E. huxleyi based on remote sensing data, but this was hampered by weather conditions prior to and during the cruise.

This paper gives an overview of the cruise and summarises physical, chemical and biological results from the cruise area. The emphasis is on results from the first transect of stations crossing the E. huxleyi bloom area on 30 June. Microplankton and its influence on the lipid composition and fecundity of Calanus finmarchicus in the same area is described by Pond et al. (1998).

\section{Methods}

A research cruise was undertaken on the RV 'Håkon Mosby' (University of Bergen, Norway; cruise 18/94) between 22 June and 5 July 1994. A bloom of the coccolithophorid, E. huxleyi was located during an initial box survey (stations 4-24) (Fig. 1), in conjunction with surface measurements of transmission (Seatech $0.25 \mathrm{~m}$ path length, $660 \mathrm{~nm}$ transmissometer) and fluorescence (Turner 112 fluorometer) via a pumped seawater supply. The bloom

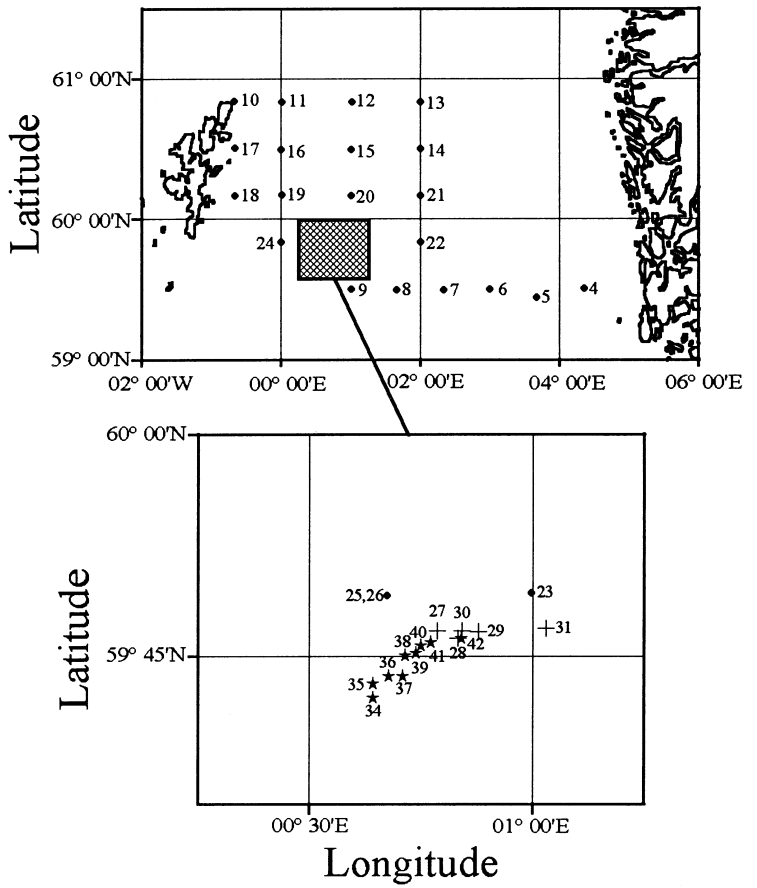

Fig. 1. 'Håkon Mosby' cruise 18/94: station positions sampled during the initial box survey. The enlargement of the stippled box indicates positions of stations sampled across the bloom of Emiliania huxleyi on 30 June (+) and 2 July (*).

of E. huxleyi was centred at approximate position $59^{\circ} 45^{\prime} \mathrm{N}$ and $00^{\circ} 45^{\prime} \mathrm{E}$ (Fig. 1). Two transects of stations across the bloom area were carried out: on 30 June (stations 27-31) and 2 July (stations 34$42)$. An enlargement of the stippled area $\left(59^{\circ} 35^{\prime} \mathrm{N}-\right.$ $60^{\circ} 00^{\prime} \mathrm{N}$ and $00^{\circ} 15^{\prime} \mathrm{E}-01^{\circ} 15^{\prime} \mathrm{E}$ ) indicates the positions of these transects (Fig. 1).

Temperature and salinity profiles were obtained with a Seabird CTD system, equipped with a rosette of Niskin bottles (101). Analysis of inorganic nutrients (nitrate, nitrite, phosphate and silicate) was conducted on freshly collected samples from the rosette, using a Skalar autoanalyser system. Samples for chlorophyll a were filtered onto GF/F filters and onboard measurements of the fluorescence of $90 \%$ acetone extracts were made before and after acidification (Yentsch and Menzel, 1963). Samples for total particulate carbon (TPC) and particulate inorganic carbon (PIC) were prepared by filtering $250 \mathrm{~cm}^{3}$ of $200-\mu \mathrm{m}$ prescreened water samples onto precombusted $25-\mathrm{mm}$ GF/F filters (washed with phosphate-buffered saline, 
and 5-mM ammonium bicarbonate, respectively) and stored at $-20^{\circ} \mathrm{C}$ for subsequent analysis. Samples for TPC were analysed on a Carlo Erba NA1500 CHN analyser using acetanilide as the calibration standard. Samples for calcite were acidified with $2 \mathrm{~cm}^{3}$ of $50 \%$ spectrasol hydrochloric acid, extracted for $12 \mathrm{~h}$ at $40^{\circ} \mathrm{C}$, diluted with $8 \mathrm{~cm}^{3}$ of $1 \%$ Lanthanum chloride and the dissolved calcium determined by atomic absorption spectroscopy employing an air-acetylene flame at $422.7 \mathrm{~nm}$ (Varian AA20). Particulate organic carbon (POC) was calculated from TPC and PIC by difference. Microscopic counting of E. huxleyi cell numbers was carried out on fresh samples in a Fuchs Rosenthal haemocytometer during the cruise. Identification and counting of phytoplankton was carried out on separate samples preserved in Lugol's iodine and borax-buffered formaldehyde. A limited number of microscopic estimates of detached coccoliths were made on the phytoplankton samples preserved in formaldehyde (Holligan et al., 1993a). Zooplankton was sampled by vertical $100-\mathrm{m}$ hauls with a $200-\mu \mathrm{m}$ WP-2 net (UNESCO, 1968).

For oxygen determinations, water was dispensed from the sampling bottles into $125 \mathrm{~cm}^{3}$ borosilicate ground glass bottles using silicone rubber tubing. To reduce exchange with the atmosphere, the silicone tubing was pushed to the bottom of each bottle during filling and the bottle was subsequently flushed with several bottle volumes prior to stoppering. Bottles were then immediately 'fixed' with $1 \mathrm{~cm}^{3}$ of each of the Winkler reagents. All bottles were titrated using a high precision automated microprocessor controlled titrator based on that described by Williams and Jenkinson (1982). The in situ temperature and salinity measurements from the CTD allowed corrections to be made for the thermal expansion of both the water sample and glass bottle. Averaged over the whole cruise, the standard error of the mean for four replicate titrations was about 1.4 mmol m $\mathrm{m}^{-3}$ (about $0.5 \%$ ).

$p \mathrm{CO}_{2}$ was calculated from daily measurements of $\mathrm{pH}_{\mathrm{NBS}}$ (using a Mettler $350 \mathrm{pH}$ meter and Ingold combination ATC probe, reading to $0.001 \mathrm{pH}$ units and calibrated with National Bureau of Standards buffers) and total alkalinity $\left(A_{\mathrm{T}}\right)$ according to a scaled down (i.e. reduced volume) version of the method of Strickland and Parsons (1972). Temperature and salinity measurements were also required using the equations provided by Dickson and Goyet (1994). $\mathrm{pH}_{\mathrm{NBS}}$ was first converted to the total hydrogen ion scale $\left(\mathrm{pH}_{\mathrm{TOT}}\right.$; see Dickson, 1993), using an apparent activity coefficient of 0.85 (see Crawford and Harrison, 1997).

Primary production was determined using simulated in situ ${ }^{14} \mathrm{C}$ incubations. Duplicate acid-washed $70-\mathrm{cm}^{3}$ polycarbonate bottles were filled with the seawater sample, spiked with $370 \mathrm{kBq}(10 \mu \mathrm{Ci})$ of $\mathrm{NaH}^{14} \mathrm{CO}_{3}$ and placed in an on-deck incubator refrigerated by circulating surface seawater. In situ irradiance levels were simulated using neutral density screens. The experiments were started between 07.00 and $08.30 \mathrm{~h}$ and lasted for $24 \mathrm{~h}$. At the end of the incubations, samples were filtered under low vacuum $(<100 \mathrm{mmHg}$ ) onto Whatman GF/F filters and immediately frozen at $-20^{\circ} \mathrm{C}$ for subsequent laboratory analysis. Radioactivity of each sample was measured on a Packard 2500 liquid scintillation counter and quenching was corrected by the channels ratio method. Calcification was measured using the microdiffusion method of Paasche and Brubak (1994).

Concentrations of ammonium and urea were measured on triplicate samples according to Solórzano (1969) and McCarthy (1970) using cells with a path length of $10 \mathrm{~cm}$. Uptake rates of ammonium, nitrate and urea, at simulated in situ conditions, were measured using ${ }^{15} \mathrm{~N}$ as a tracer. Additions of 0.05 $\mu \mathrm{mol} \mathrm{dm}{ }^{-3}$ of ${ }^{15} \mathrm{~N}$ ammonium (95 atom \%) or ${ }^{15} \mathrm{~N}$ urea-N (99 atom \%) or $0.05 \mu \mathrm{mol} \mathrm{dm}{ }^{-3}{ }^{15} \mathrm{~N}$ nitrate $(96.8$ atom $\%)$ or ${ }^{15} \mathrm{~N}$ nitrite $(96.8$ atom \%) were made to separate incubation bottles. The incubation bottles were covered with neutral density screening and placed in deck incubators maintained at in situ temperature using circulating surface seawater. The incubations were terminated after $4-6 \mathrm{~h}$ by filtering onto precombusted $25-\mathrm{mm}$ Whatman GF/F filters. Filter samples were prepared for isotope analysis and the atom $\%{ }^{15} \mathrm{~N}$ was determined by emission spectrometry using a Jasco Model N-150 N-15 Analyzer as described in Kristiansen and Paasche (1989).

\section{Results}

\subsection{Physical, chemical and biological data}

The study area was typically characterised by strong stratification $\left(2-5^{\circ} \mathrm{C}\right)$, but stations adjacent 
Table 1

Summary surface $(3 \mathrm{~m})$ data for the study area ${ }^{\mathrm{a}}$

\begin{tabular}{|c|c|c|c|c|c|c|c|c|c|c|c|c|}
\hline \multirow[t]{2}{*}{ Variable } & \multicolumn{3}{|c|}{ (A) Non-stratified } & \multicolumn{3}{|c|}{ (B) Stratified } & \multicolumn{3}{|c|}{ (C) Stations 27-31 } & \multicolumn{3}{|c|}{ (D) Stations 34-42 } \\
\hline & Mean & Range & SD & Mean & Range & SD & Mean & Range & SD & Mean & Range & SD \\
\hline Temperature $\left({ }^{\circ} \mathrm{C}\right)$ & 9.63 & $9.28-9.98$ & 0.35 & 9.92 & $9.62-10.21$ & 0.21 & 10.08 & $10.06-10.17$ & 0.02 & 11.30 & $10.87-11.91$ & 0.3 \\
\hline$\Delta T\left({ }^{\circ} \mathrm{C}, 0-60 \mathrm{~m}\right)$ & 0.33 & $0.07-0.65$ & 0.29 & 2.30 & $1.10-2.91$ & 0.61 & 4.06 & $3.85-4.17$ & 0.12 & 5.22 & $4.73-5.96$ & 0.42 \\
\hline Salinity (P.S.U.) & 34.97 & $34.70-35.12$ & 0.23 & 35.09 & $34.69-35.33$ & 0.33 & 35.12 & $35.12-35.14$ & 0.01 & 35.12 & $35.10-35.16$ & 0.02 \\
\hline $\begin{array}{l}\text { E. huxleyi cells } \\
\qquad\left(10^{6} \mathrm{dm}^{-3}\right)\end{array}$ & 0.45 & $0.00-1.05$ & 0.54 & 0.14 & $0.00-0.60$ & 0.20 & 2.24 & $0.00-4.50$ & 1.93 & 1.03 & $0.00-3.20$ & 1.20 \\
\hline $\mathrm{Chl}\left(\mathrm{mg} \mathrm{m}^{-3}\right)$ & 0.70 & $0.50-0.81$ & 0.17 & 1.36 & $0.32-3.80$ & 0.87 & 0.91 & $0.54-1.85$ & 0.64 & 0.39 & $0.28-0.70$ & 0.12 \\
\hline $\mathrm{POC}\left(\mu \mathrm{g} \mathrm{dm}^{-3}\right)$ & 244.2 & $198.9-289.4$ & 64.0 & 267.8 & $143.2-375.3$ & 74.6 & 203.1 & $185.8-226.3$ & 18.8 & 183.8 & $155.4-202.1$ & 15.2 \\
\hline PIC $\left(\mu \mathrm{g} \mathrm{dm}^{-3}\right)$ & 18.1 & $6.7-29.5$ & 16.1 & 12.1 & $2.0-42.9$ & 15.9 & 26.6 & $5.7-42.9$ & 15.4 & 22.0 & $13.7-44.6$ & 12.8 \\
\hline $\mathrm{PON}\left(\mu \mathrm{g} \mathrm{dm}^{-3}\right)$ & 39.1 & $30.6-47.6$ & 12.0 & 42.3 & $25.2-62.7$ & 11.4 & 30.2 & $28.9-31.4$ & 1.04 & 26.5 & $21.9-30.3$ & 3.8 \\
\hline $\mathrm{NO}_{3}\left(\mu \mathrm{M} \mathrm{dm}{ }^{-3}\right)$ & 3.79 & $3.08-4.95$ & 1.01 & 1.35 & $0.00-4.92$ & 1.76 & 0.05 & $0.00-0.09$ & 0.04 & 0.00 & $0.00-0.02$ & 0.00 \\
\hline $\mathrm{SiO}_{4}\left(\mu \mathrm{M} \mathrm{dm}{ }^{-3}\right)$ & 1.34 & $1.03-1.56$ & 0.27 & 0.98 & $0.51-1.88$ & 0.41 & 0.89 & $0.81-0.96$ & 0.06 & 0.82 & $0.77-0.90$ & 0.05 \\
\hline $\mathrm{PO}_{4}\left(\mu \mathrm{M} \mathrm{dm}{ }^{-3}\right.$ & 0.62 & $0.60-0.64$ & 0.02 & 0.44 & $0.29-0.70$ & 0.12 & 0.33 & $0.26-0.36$ & 0.04 & 0.34 & $0.33-0.37$ & 0.01 \\
\hline
\end{tabular}

a (A) non-stratified stations; (B) stratified stations outside the bloom area; (C) first transect (stations 27-31); and (D) second transect (stations 34-42) across the bloom area.

to the Shetland Islands were either well mixed or weakly stratified $\left(<1^{\circ} \mathrm{C}\right)$ due to increased tidal flow. Table 1 lists mean surface hydrographic variables for: (A) the weak or non-stratified water mass to the east of the Shetlands; (B) the stratified regime containing stations sampled during the initial box survey; (C) the first transect across the bloom on the 30 June; and (D) the second transect across the bloom on 2 July.

The horizontal distribution of temperature and salinity over the cruise area showed lowest values of $9.28^{\circ} \mathrm{C}$ and 34.69 P.S.U., associated with near-shore non-stratified stations to the northwest of the study area. Between 30 June and 2 July, surface temperature in the area of the bloom of E. huxleyi increased from $\sim 10^{\circ}$ to $>11.5^{\circ} \mathrm{C}$. Highest surface nutrient concentrations (nitrate, $4.95 \mu \mathrm{M}$; silicate, $1.88 \mu \mathrm{M}$; and phosphate, $0.70 \mu \mathrm{M}$ ) and lowest chlorophyll a concentration $\left(0.30 \mathrm{mg} \mathrm{m}^{-3}\right)$ were found in the area of weakest stratification (stations 10, 11 and 17). To the south and east, depleted nutrient concentrations and higher chlorophyll a concentrations ( $>1 \mathrm{mg}$ chl $\mathrm{m}^{-3}$ ) were observed with the highest chlorophyll a concentration at station $24\left(3.80 \mathrm{mg} \mathrm{chl} \mathrm{m}^{-3}\right)$. POC concentrations were generally in the range 150-250 $\mu \mathrm{g} \mathrm{C} \mathrm{dm}{ }^{-3}$, but higher values (>350 $\mu \mathrm{g} \mathrm{C} \mathrm{dm}^{-3}$ ) were observed at stations 14 and 15 . Surface abundance of E. huxleyi was generally low $\left(<0.60 \times 10^{6}\right.$ cells $\mathrm{dm}^{-3}$ ) outside the bloom area, but mean values of $0.45 \times 10^{6} \mathrm{dm}^{-3}$ cells (range $0-1.05 \times 10^{6}$ cells $\mathrm{dm}^{-3}$ ) were observed in the near-shore stations to the northwest. The highest cell concentration was observed at station $25\left(6 \times 10^{6}\right.$ cells $\left.\mathrm{dm}^{-3}\right)$.

\subsection{Transects across the bloom of E. huxleyi on 30 June and 2 July}

The average concentrations of variables are given in Table 1. We have concentrated here on the results from the first transect of stations 27-31 on 30 June. As the results obtained on the second transect of stations $34-42$ on 2 July were generally similar, they have been treated in less detail.

There was an inverse relationship between $E$. huxleyi cell abundance and chlorophyll a concentration. Whilst the numbers of E. huxleyi were $>3 \times 10^{6}$ cells $\mathrm{dm}^{-3}$ at station 27 , moving eastwards along the transect, numbers decreased to $<0.1 \times 10^{6}$ cells

Fig. 2. Vertical sections of (A) cell abundance of Emiliania huxleyi, (B) chlorophyll a, (C) particulate organic carbon, (D) particulate inorganic carbon, $(\mathrm{E})$ temperature, $(\mathrm{F})$ nitrate, $(\mathrm{G})$ silicate, and $(\mathrm{H})$ phosphate during the transect of stations $27-31$ across the bloom of $E$. huxleyi on 30 June 1994. The symbol • indicates the sampling depths from station 27 (at left) to station 31 (at right). Positions as in Fig. 1. 

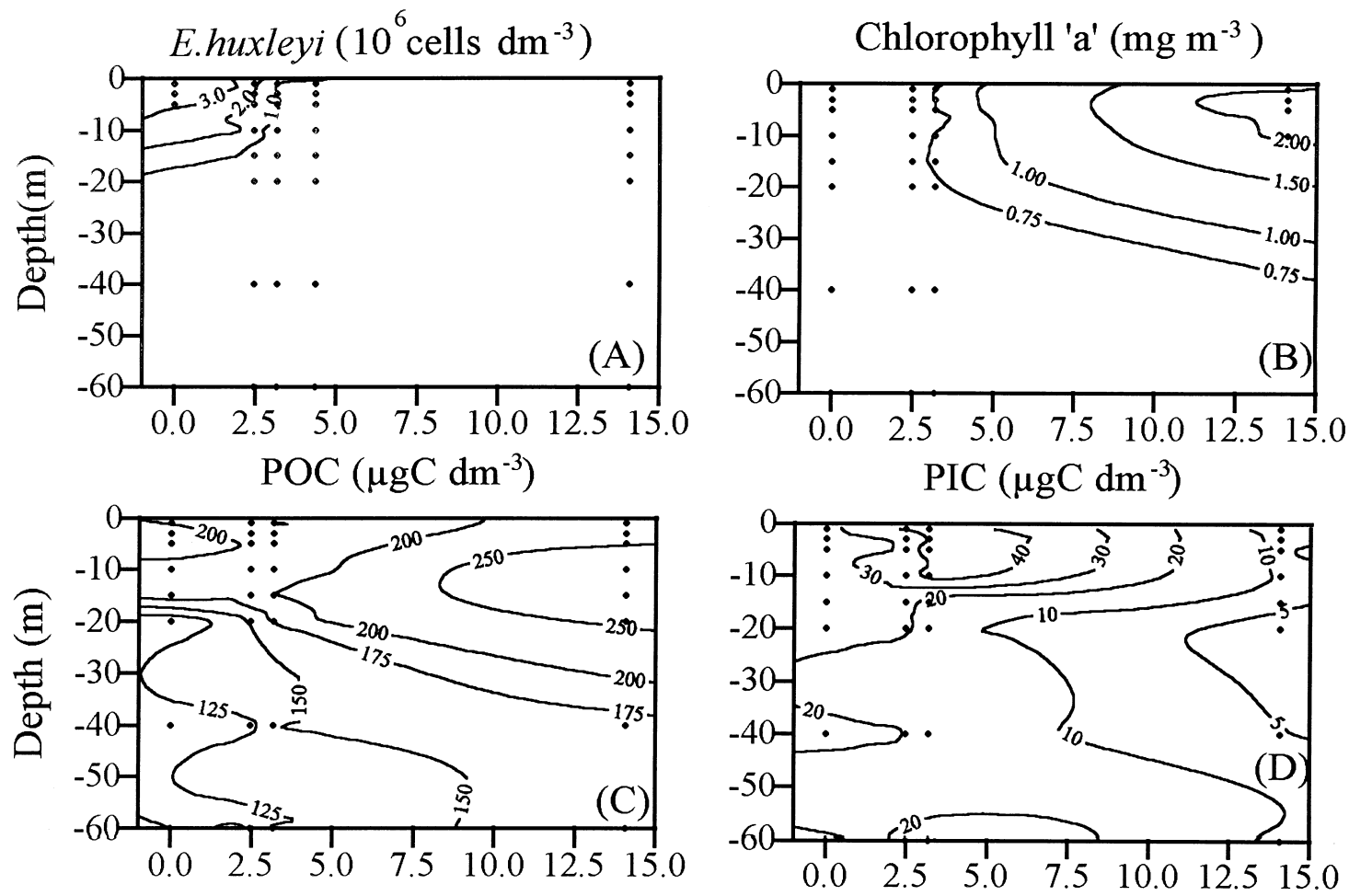

Temperature $\left({ }^{\circ} \mathrm{C}\right)$

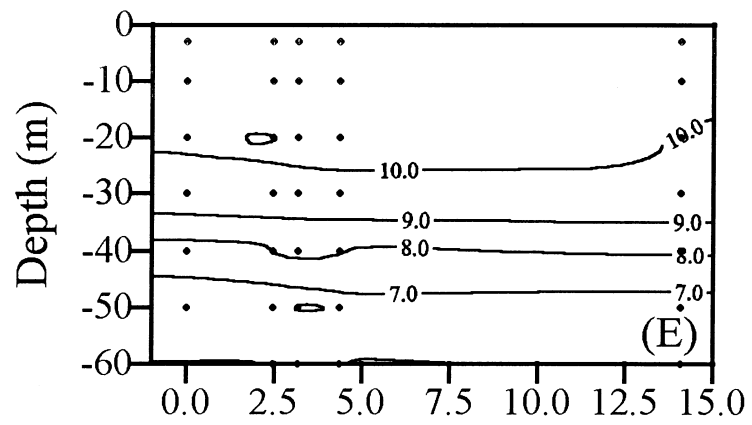

Silicate $\left(\mu \mathrm{M} \mathrm{dm}^{-3}\right)$

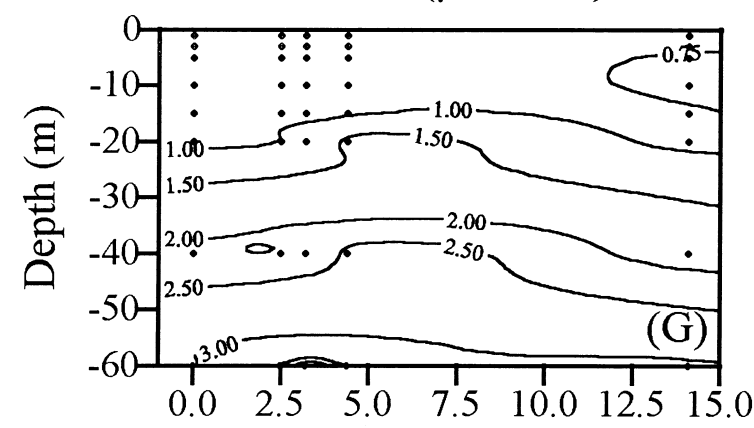

Distance in $\mathrm{km}$

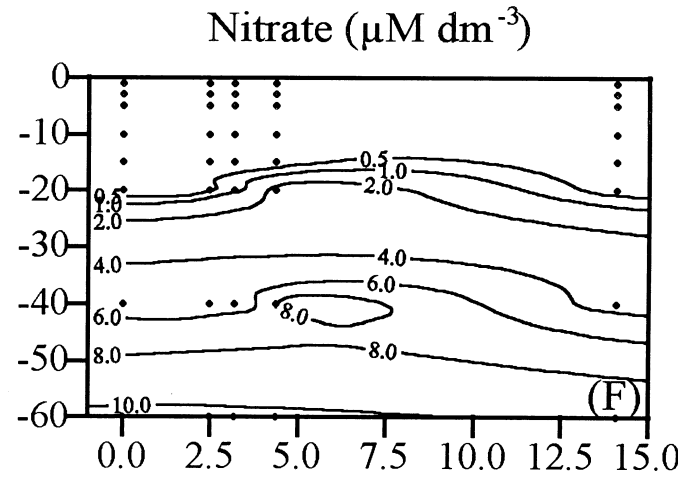

Phosphate $\left(\mu \mathrm{M} \mathrm{dm}^{-3}\right)$

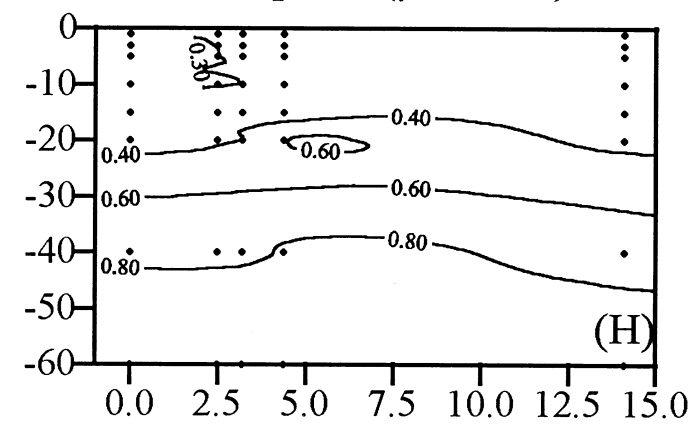

Distance in $\mathrm{km}$ 
$\mathrm{dm}^{-3}$ at station 31 (Fig. 2A). The highest levels of integrated chlorophyll a (70-80 $\mathrm{mg} \mathrm{m}^{-2}$ ) occurred where the abundance of E. huxleyi was low $\left(<1 \times 10^{6}\right.$ cells $\left.\mathrm{dm}^{-3}\right)$. The bloom of E. huxleyi was associated with much lower levels of chlorophyll a $\left(<0.75 \mu \mathrm{g} \mathrm{chl} \mathrm{dm}^{-3}\right)$. A small number of samples were taken within the bloom for estimates of numbers of detached liths on both transects. Maximum numbers of liths $\left(2-3 \times 10^{4}\right.$ liths $\left.\mathrm{cm}^{-3}\right)$ were observed at station 27 on the first transect on 30 June and station 39 on the second transect on 2 July. Numbers of both diatoms and dinoflagellates increased eastwards along the transect and this is reflected in the elevated chlorophyll a values observed at station 31 (Fig. 2B). Corethron hystrix, Eucampia zoodiacus and Rhizosolenia spp. were the dominant diatom species whilst Prorocentrum balticum was the dominant dinoflagellate.

Concentrations of POC (Fig. 2C) were consistent in the upper $20 \mathrm{~m}$ in the bloom area at stations 27-30 with typical values of 200-230 $\mu \mathrm{g} \mathrm{C} \mathrm{dm}^{-3}$ observed. The POC maxima ( $>350 \mu \mathrm{g} \mathrm{C} \mathrm{dm}^{-3}$ ) were associated with the higher chlorophyll a in the diatom bloom at station 31. Values of PIC (Fig. 2D) were highest in the bloom area with observed values of $27-50 \mu \mathrm{g} \mathrm{C} \mathrm{dm}^{-3}$ at stations 27-30 in the upper $20 \mathrm{~m}$; much lower concentrations of $<10 \mu \mathrm{g} \mathrm{C} \mathrm{dm}^{-3}$ were observed at station 31 . There was a near surface maximum in PIC of $>40 \mu \mathrm{g} \mathrm{C} \mathrm{dm}^{-3}$, but this was slightly offset away from the bloom at station 27 in the vicinity of station 30 . The bloom did not appear to be associated with physical structure as the thermocline depth across the transect was 25-30 m. Surface to $60 \mathrm{~m}$ temperature differences across the transect were consistent at $4.06 \pm 0.12^{\circ} \mathrm{C}$ (Fig. 2E). In the surface mixed layer the mean temperature and salinity were $10.08 \pm 0.02^{\circ} \mathrm{C}$ and $35.12 \pm 0.01$ P.S.U. The $1 \%$ isolumen values at stations within the bloom area were identical to levels found in stations outside the bloom area $(23 \pm 0.5 \mathrm{~m}$ and $22 \pm$ $3.8 \mathrm{~m}$, respectively). Concentrations of inorganic nutrients were either low or depleted in the upper $20 \mathrm{~m}$ with concentrations of nitrate, phosphate and silicate of less than $0.2,0.3$ and $1.0 \mu \mathrm{M}$, respectively (Fig. 2F-H).

Distribution of oxygen saturation showed maxima in the upper 10-20 m, associated with the bloom of E. huxleyi around station 27, and with the bloom of diatoms at station 31 (Fig. 3A). Distribution of dissolved oxygen was consistent with elevated production of $\mathrm{O}_{2}$ by diatoms ( $>107 \%$ saturation) at station 31, where the elevated levels of POC and chlorophyll a were also observed. In contrast, and in confirmation of the low chlorophyll levels, organic productivity seemed to be lower in the bloom of $E$. huxleyi, as $\mathrm{O}_{2}$ levels were between 103 and $105 \%$ saturation (Fig. 3A).

Observed surface values of $p \mathrm{CO}_{2}$ across the transect were either equal to or slightly greater than atmospheric equilibrium (Fig. 3B). There was an inverse relationship between $p \mathrm{CO}_{2}$ concentration and $\mathrm{O}_{2}$ saturation, with minimum values associated with the diatom bloom around station 31. Values gradually increased westwards across the transect, and within the bloom of E. huxleyi, surface values exceeded $380 \mu \mathrm{atm}$. A total alkalinity $\left(A_{\mathrm{T}}\right)$ minimum was observed within the depth zone of $0-10 \mathrm{~m}$ (Fig. 3C), associated with the bloom of E. huxleyi at station 27. $A_{\mathrm{T}}$ was not normalised to constant salinity because the salinity variation was minimal both across the transect and with depth. The decrease in $A_{\mathrm{T}}$ was very small, however, with values of $10-20$ $\mu \mathrm{mol} \mathrm{\textrm {kg } ^ { - 1 }}$ below ambient levels. PIC was not consistent with either an inverse relationship with $A_{\mathrm{T}}$, or a direct proportional relationship with the abundance of E. huxleyi.

The POC/chlorophyll a ratio gave a maximum value of $357 \mu \mathrm{g} \mathrm{C} \mu \mathrm{g} \mathrm{chl}{ }^{-1}$ at station $27 \mathrm{de}-$ creasing along the transect to a minimum of 71 $\mu \mathrm{g} \mathrm{C} \mu \mathrm{g} \mathrm{chl}^{-1}$ at station 31 (Fig. 4A). Observations on photosynthetic rate are reported from $3-\mathrm{m}$ depth along the transect of stations 27-31. The maximum photosynthetic rate of $134.4 \mu \mathrm{g} \mathrm{C} \mathrm{dm}^{-3} \mathrm{~d}^{-1}$ was observed at station 31. Much lower values of 50.8-67.7 $\mu \mathrm{g} \mathrm{C} \mathrm{dm}^{-3} \mathrm{~d}^{-1}$ were observed at stations $27-30$ in association with the E. huxleyi bloom. The average integrated photosynthesis at the bloom stations was $3.2 \pm 1.3 \mathrm{mg} \mathrm{C} \mathrm{m} \mathrm{m}^{-2} \mathrm{~d}^{-1}$ compared with $1.1 \pm 0.1 \mathrm{mg} \mathrm{C} \mathrm{m}^{-2} \mathrm{~d}^{-1}$ at the stations located outside the bloom. Conversely, the maximum photosynthesis/chlorophyll ratios of 80.9-96.2 $\mu \mathrm{g}$ C $\mu \mathrm{g} \mathrm{chl}^{-1} \mathrm{~d}^{-1}$ were observed at stations 27-30 with the lowest value of $47.3 \mu \mathrm{g} \mathrm{C} \mu \mathrm{g} \mathrm{chl}{ }^{-1} \mathrm{~d}^{-1}$ recorded at station 31 (Fig. 4B). Calculated ratios of calcification/photosynthesis varied between 0.14 at station 27 decreasing to 0.03 at station 31 . The large 

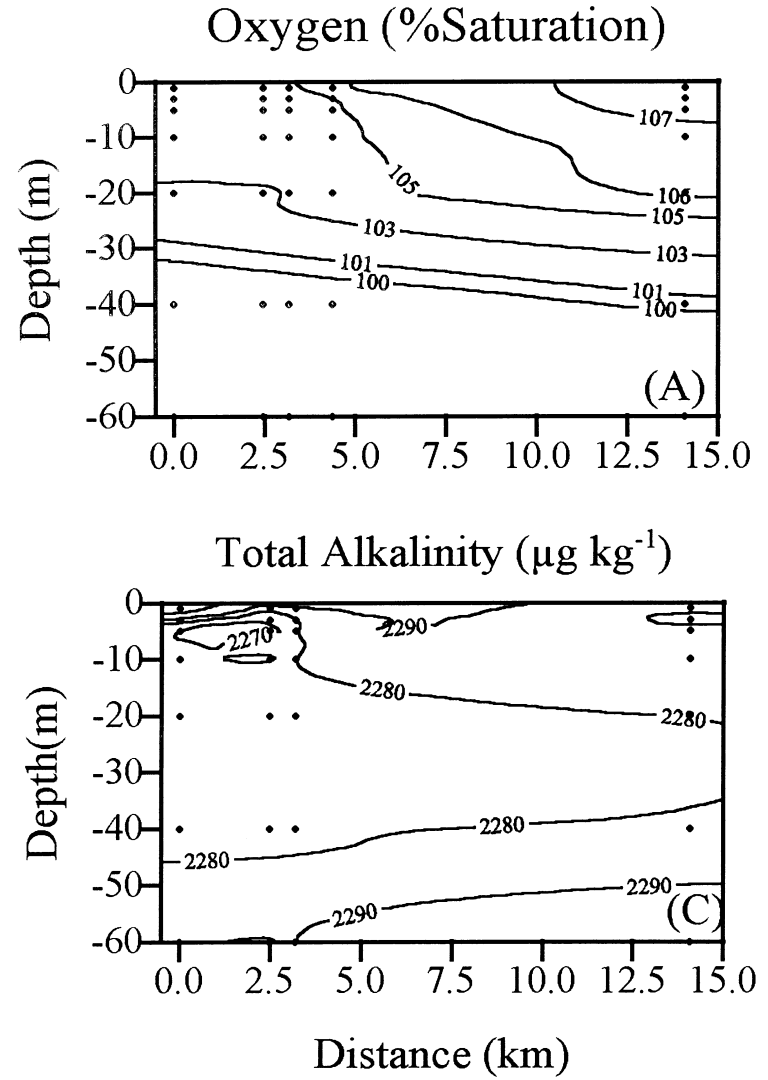

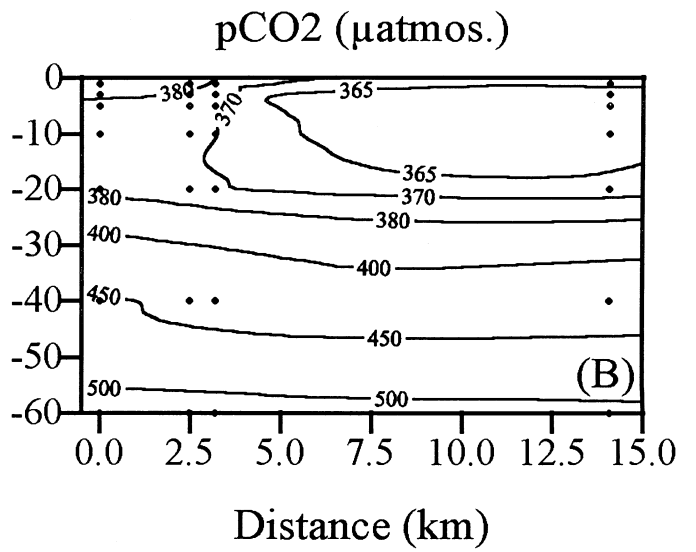

Fig. 3. Vertical sections of (A) oxygen, (B) $\mathrm{pCO}_{2}$ and (C) total alkalinity during the transect of stations across the bloom of Emiliania huxleyi on 30 June 1994. The symbol • indicates the sampling depths from station 27 (at left) to station 31 (at right). Positions as in Fig. 1.

variations in the values observed at stations $27-30$, in comparison with measurements made at station 31 , are attributable to the different phytoplankton assemblages at those stations. On the second transect on 2 July, a significant relationship was observed between $p \mathrm{CO}_{2}$ concentration and photosynthesis $\left(r^{2}=0.553\right.$, $p<0.01)$. On the same transect no significant relationship was observed between $p \mathrm{CO}_{2}$ concentration and calcification (Fig. 5).

Nutrient uptake rates in nmol $\mathrm{dm}^{-3} \mathrm{~h}^{-1}$ for ammonium, nitrate, nitrite and amino acids along the transect from a depth of $3 \mathrm{~m}$ are shown in Fig. 6A. Observed urea uptake rates were low $(<0.02 \mathrm{nmol}$ $\mathrm{dm}^{-3} \mathrm{~h}^{-1}$ ) at all stations. At station 27, the $f$-ratio (the ratio between nitrate uptake rate and nitrate + ammonium + urea uptake rates) was low (0.17). The major nitrogen source for growth was ammonium which accounted for $82 \%$ of summed uptake rates.
At stations $28-31$ there was an increase in $f$-ratio to $\sim 0.5$ indicating assimilation of both ammonium and nitrate equally (Fig. 6B).

\subsection{Zooplankton species composition}

The mean numerical distribution of dominant groups of mesozooplankton for non-stratified and stratified regimes in the initial box survey and for stations $27-31$ in the bloom area is shown in Table 2. In stratified waters including the bloom area, the dominant species were Calanus finmarchicus followed by Oithona sp., Para/Pseudocalanus spp. and Microcalanus. In the mixed regime, the numerically dominant species were Para/Pseudocalanus spp. followed by Calanus finmarchicus, Temora, lamellibranch larvae and Metridia lucens.

Fig. 7 shows the numerical distribution of the six 

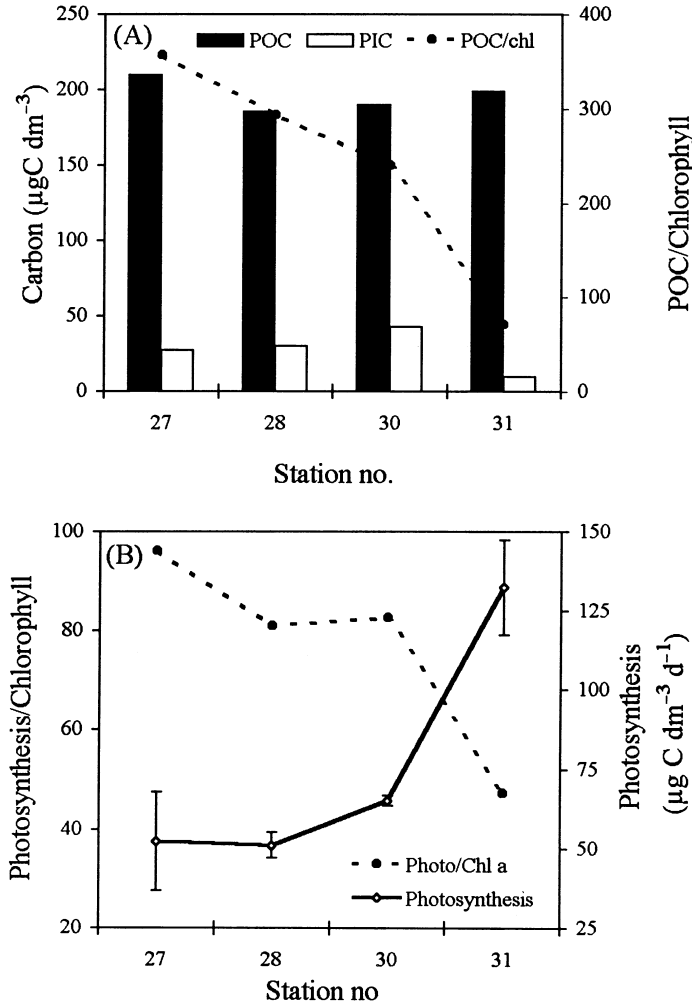

Fig. 4. Discrete measurements made at $3 \mathrm{~m}$ depth over stations 27-31 of: (A) particulate organic carbon (POC in $\mu \mathrm{g} \mathrm{C} \mathrm{dm}^{-3}$ ), particulate inorganic carbon (PIC in $\mu \mathrm{g} \mathrm{C} \mathrm{dm}^{-3}$ ), and ratio of particulate organic carbon to chlorophyll a $\left(\mu \mathrm{g} \mathrm{C} \mu \mathrm{g} \mathrm{chl}^{-1}\right)$; and (B) ${ }^{14} \mathrm{C}$ photosynthesis $\left(\mu \mathrm{g} \mathrm{C} \mathrm{dm}{ }^{-3} \mathrm{~d}^{-1}\right)$ and ratio of photosynthesis to chlorophyll a $\left(\mu \mathrm{g} \mathrm{C} \mu \mathrm{g} \mathrm{Chl}^{-1} \mathrm{~d}^{-1}\right)$. Positions as in Fig. 1.

dominant zooplankton groups from stations 27-31. At stations 27 and 28 , the dominant species was C. finmarchicus (293 and $526 \mathrm{~m}^{-3}$, respectively). At stations 30 and 31 , in addition to $C$. finmarchicus (561 and $218 \mathrm{~m}^{-3}$ ), increased numbers of Oithona spp. (218 and $231 \mathrm{~m}^{-3}$ ), copepod nauplii (70 and $49 \mathrm{~m}^{-3}$ ) and Microcalanus (70 and $68 \mathrm{~m}^{-3}$ ) were present.

\section{Discussion}

\subsection{The relationship between hydrography and the origin of the bloom}

The origin and development of E. huxleyi populations within the North Sea ecosystem are not well

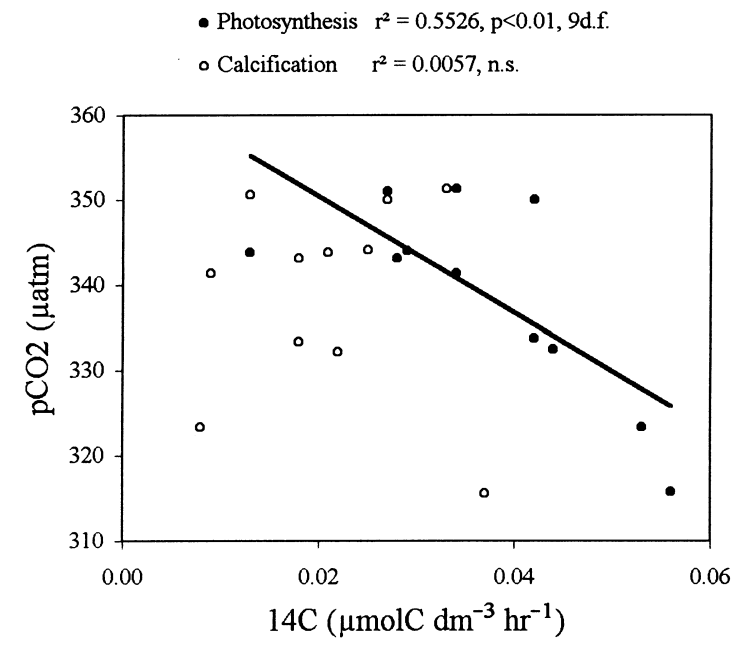

Fig. 5. Variation of $p \mathrm{CO}_{2}$ with photosynthesis (•) (in $\mu \mathrm{mol} \mathrm{C}$

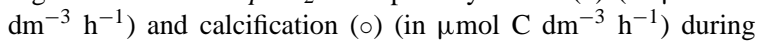
the transect of stations $34-42$ on 2 July.
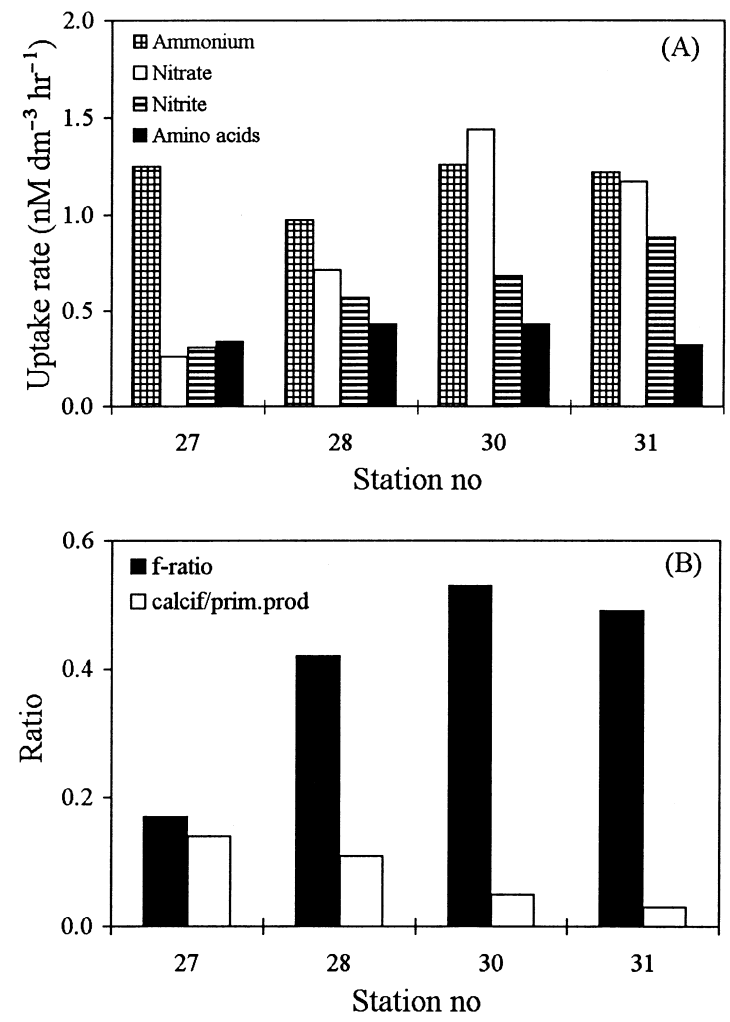

Fig. 6. Discrete measurements made at $3 \mathrm{~m}$ depth over stations 27-31: (A) nutrient uptake rates of ammonium, nitrate, nitrite and amino acids (nmol dm ${ }^{-3} \mathrm{~h}^{-1}$ ); (B) $f$-ratio and calcification to primary production ratios; for stations $27-31$. Positions as in Fig. 1. 
Table 2

Summary of dominant zooplankton (numbers $\mathrm{m}^{-3}$ ) in non-stratified and stratified waters outside the bloom area and during the first transect on 30 June (stations 27-31) ${ }^{\mathrm{a}}$

\begin{tabular}{lrrr}
\hline Species & Non-stratified & Stratified & $\begin{array}{l}\text { Stations } \\
27-31\end{array}$ \\
\hline Calanus finmarchicus & 385 & 255 & 428 \\
Oithona sp. & 167 & 99 & 125 \\
Metridia lucens & 59 & 14 & 18 \\
Microcalanus sp. & 11 & 18 & 37 \\
Para/Pseudocalanus spp. & 3026 & 34 & 13 \\
Copepod nauplii & 0 & 10 & 31 \\
Acartia sp. & 17 & 0 & 0 \\
Centropages hamatus & 26 & 0 & 0 \\
Temora sp. & 91 & 0 & 0 \\
Lamellibranch larvae & 65 & 0 & 0 \\
\hline
\end{tabular}

${ }^{\text {a }}$ Zooplankton sampled in the upper $100 \mathrm{~m}$.

understood. The inflow of Atlantic water from the north is considered to be a major source of cells (Houghton, 1991) and the frequent occurrence of blooms north of $58^{\circ} \mathrm{N}$ is thought to be consistent with patterns of water movement and distributions of high salinity water in this area (Turrell et al., 1992). A previous study conducted within the same area during June/July 1993 (Van der Wal et al., 1995) has shown that the E. huxleyi population was related

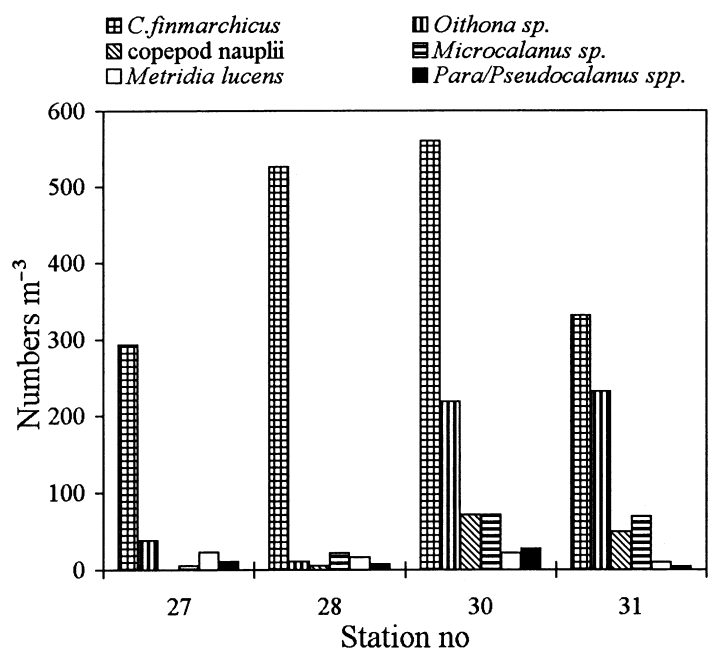

Fig. 7. Numerically dominant zooplankton $\left(n \mathrm{~m}^{-3}\right)$ for stations 27-31: Calanus finmarchicus, Oithona sp., copepod nauplii, Microcalanus, Metridia lucens, and Para/Pseudocalanus. Zooplankton sampled throughout the upper $100 \mathrm{~m}$ of the water column. Positions as Fig. 1. to the spread of low-saline run-off waters, which may have assisted the formation of a stable shallow mixed layer. In the current study, the prevailing cloudy weather conditions, both prior to and during the study period, prevented satellite imagery being used to indicate the stage or evolution of the bloom. Tidal streams in the northern North Sea are generally low (Otto et al., 1990) and it may well be that wind stress is an important feature in the origin of bloom formation in this area (Pingree and Griffiths, 1982). During summer, the seasonal western displacement of the Norwegian Coastal Water is due to the Ekman transport driven by increased northerly wind stress (Saetre et al., 1988). The outflow from fjords can be very pronounced and long periods of northerly winds can produce plumes of brackish water $>80$ $\mathrm{km}$ offshore (Otto et al., 1990).

Observations on E. huxleyi cell densities and hydrography carried out on the initial box survey of stations (stations 4-24) did not indicate any westward spread of low-salinity water or elevated concentrations of E. huxleyi cells towards the bloom area. These observations and the general circulation patterns of the northern North Sea as described in Otto et al. (1990), would indicate association of the 1994 bloom with higher salinity Atlantic water, rather than low-salinity run-off from the Norwegian fjords.

\subsection{The state of development of the bloom}

In the E. huxleyi bloom area (defined where the surface concentration of E. huxleyi cells was $>1 \times 10^{6}$ cells $\mathrm{dm}^{-3}$ ), we observed high cell concentrations between $1 \times 10^{6}$ cells dm$~^{-3}$ and $6 \times 10^{6}$ cells $\mathrm{dm}^{-3}$ (Fig. 2A). These values are comparable with previous studies made in the North Atlantic (Fernández et al., 1993), the North Sea (Van der Wal et al., 1995) and the English Channel (García-Soto et al., 1995). In contrast to those studies, the PIC levels we measured were lower by a factor of 3-6 $\left(<50 \mu \mathrm{g} \mathrm{C} \mathrm{dm}^{-3}\right.$ as compared to $150-300 \mu \mathrm{g} \mathrm{C}$ $\mathrm{dm}^{-3}$ ). Similarly, PIC/POC ratios (Fig. 5A) were much lower $(<0.25$ compared with 0.6 to $>4)$. The density of detached liths (even though we only collected a small number of samples) was an order of magnitude lower with values of $2-3 \times 10^{4}$ liths $\mathrm{cm}^{-3}$ in contrast to observations of $2-3 \times 10^{5}$ liths cm $\mathrm{cm}^{-3}$ in previous studies where oceanic blooms had entered a 
decaying phase. The bloom in the present study was sampled over a period of 8 days and the combination of high cell densities, together with low concentrations of both PIC and numbers of detached liths lead us to conclude that the bloom in this study was at an early stage of development.

Comparison of this study with other field studies reveals a common hydrographic feature with most blooms of E. huxleyi. Blooms occur in highly stratified water within a shallow mixed layer of $\sim 30 \mathrm{~m}$ or less. This has been shown in studies in the English Channel (García-Soto et al., 1995), the northern North Sea (Van der Wal et al., 1995), the North Atlantic (Fernández et al., 1993; Holligan et al., 1993a), the Gulf of Maine (Balch et al., 1991, 1992; Matrai and Keller, 1993; Townsend et al., 1994) and in Norwegian fjords (Kristiansen et al., 1994). The blooms always appear to develop in the early summer within a temperature range of $10-16^{\circ} \mathrm{C}$ following the decline of the spring diatom bloom. Surface levels of inorganic nutrients within the surface mixed layer are either low or depleted. Egge and Heimdal (1994) and modelling studies with North Atlantic data (Tyrrell and Taylor, 1996) have shown that E. huxleyi can bloom successfully both in mesocosms and oceanic waters with low or depleted levels of phosphate.

Zooplankton distribution showed little difference between the bloom and non-bloom stations, with the exception of the high numbers of Para/Pseudocalanus in the non-stratified waters. The abundance of Calanus finmarchicus was comparable to, but higher than, that reported for C. helgolandicus in shelf-break and oceanic blooms in the North Atlantic (Harris, 1994). Evidence on the possible effects of E. huxleyi blooms on zooplankton populations is not clear. On the one hand Nejstgaard et al. (1997) report active feeding and reproduction by zooplankton in mesocosm experiments, whereas Wolfe et al. (1997) provide evidence of chemical defence against grazing. The present results are not sufficient to determine whether there was an effect of the bloom on the zooplankton population.

In oceanic waters, POC levels attributable to $E$. huxleyi cells within blooms of this species are low compared to the total community POC, with typical values of $10-90 \mu \mathrm{g} \mathrm{C} \mathrm{dm}^{-3}$ representing 5-25\% of the total (Balch et al., 1991; Holligan et al., 1993a). In this study, assuming a cell carbon content of 13 pg (Holligan et al., 1984), the observed cellular POC levels of E. huxleyi cells in the blooming area were similar, with a range of $13-40 \mu \mathrm{g} \mathrm{C} \mathrm{dm}^{-3}$ and equivalent to $6.4-19.7 \%$ of the total community POC. In mesocosm experiments, the amount of particulate organic carbon in living cells of E. huxleyi may be as much as $500 \mu \mathrm{g} \mathrm{dm}^{-3}$ (Van Bleijswijk et al., 1994). Even though the POC values are much higher, the percentage of total-community POC is very similar with a range of $13-45 \%$ observed.

\subsection{The biological implications of the bloom}

Rates of organic carbon fixation were significantly lower in the bloom area than measurements taken outside the bloom, where diatoms and dinoflagellates were more abundant (Fig. 4B). The average value of integrated photosynthesis at the bloom stations was $1.1 \pm 0.1 \mathrm{mg} \mathrm{C} \mathrm{m}^{-2} \mathrm{~d}^{-1}$ compared with $3.2 \pm 1.3$ $\mathrm{mg} \mathrm{C} \mathrm{m} \mathrm{m}^{-2} \mathrm{~d}^{-1}$ in stations located outside the bloom area. A decrease in primary productivity associated with the occurrence of E. huxleyi blooms has been found previously in both mesocosm (Marañón et al., 1996) and open ocean studies (Balch et al., 1991; Van der Wal et al., 1995). The changes in the photosynthesis to chlorophyll a ratio across the transect between stations 27 and 31 could suggest that photosynthetic efficiency was higher within the E. huxleyi bloom. However, when considering a total of 12 productivity stations sampled throughout the cruise, the average photosynthesis to chlorophyll a ratio in coccolithophore-rich waters $\left(25.4 \pm 4.8 \mathrm{mg} \mathrm{C} \mathrm{mg} \mathrm{chl}^{-1}\right.$ $\mathrm{d}^{-1}$ ) was not significantly different from that measured outside the bloom area $(28.56 \pm 6.2 \mathrm{mg} \mathrm{C} \mathrm{mg}$ $\mathrm{chl}^{-1} \mathrm{~d}^{-1}$ ) (table 2 of Marañón and González, 1997). Our results indicate that reduced rates of organic carbon production in bloom waters were probably due to lower levels of photosynthetic biomass rather than to a decrease in the photosynthetic efficiency of microalgae.

Elevated $p \mathrm{CO}_{2}$ values have been observed in E. huxleyi blooms in both oceanic waters (Holligan et al., 1993a; Robertson et al., 1994) and mesocosms (Purdie and Finch, 1994), but the relative importance of several potential mechanisms responsible for such an increase have not been clarified (Crawford and Purdie, 1997). It has been shown theoretically that growth of E. huxleyi can either decrease the air-sea 
gradient in $p \mathrm{CO}_{2}$ driven by 'organic' production or depending on the relative rates of photosynthesis, calcification and respiration, could cause a direct elevation in $p \mathrm{CO}_{2}$ levels (Crawford and Purdie, 1997; Nimer et al., 1992; Steemann Nielsen, 1966). In addition to the possible production of $\mathrm{CO}_{2}$ as a result of calcification (Robertson et al., 1994), a reduction in the air-sea $p \mathrm{CO}_{2}$ gradient at the western end of the transect could also result from the lower rates of carbon fixation in comparison with values observed in the diatom-dominated assemblages to the east. Both processes might well account for the observed increase in surface $p \mathrm{CO}_{2}$ levels in coccolithophore-rich waters at the western end of the transect (Fig. 3B).

\subsection{Concluding remarks}

In conclusion, we present a study of a bloom of $E$. huxleyi which was in an early developmental stage. The hydrographic conditions including the physical structure associated with this bloom of E. huxleyi were similar to characteristics described for oceanic and shelf blooms in the North Atlantic (Fernández et al., 1993), the Gulf of Maine (Balch et al., 1992; Townsend et al., 1994) and the Western English Channel (García-Soto et al., 1995). The bloom was associated with Atlantic waters and was confined to an area in which a stable shallow mixed layer had formed.

\section{Acknowledgements}

We wish to thank the captain and crew of the RV 'Håkon Mosby' for their help at sea. The cruise was financially supported by the Norwegian Research Council, and the MAST-II EHUX project, Contract MAS2-CT92-0038. This is EHUX contribution No. 64.

\section{References}

Balch, W.M., Holligan, P.M., Ackleson, S.G., Voss, K.J., 1991. Biological and optical properties of mesoscale coccolithophore blooms in the Gulf of Maine. Limnol. Oceanogr. 36, 629-643.

Balch, W.M., Holligan, P.M., Kilpatrick, K.A., 1992. Calcification, photosynthesis and growth of the bloom-forming coccolithophore, Emiliania huxleyi. Cont. Shelf Res. 12, 13531374.
Brown, C.W., Yoder, J.A., 1993. Blooms of Emiliania huxleyi (Prymnesiophyceae) in surface waters of the Nova Scotia Shelf and Grand Bank. J. Plankton Res. 15, 1429-1438.

Brown, C.W., Yoder, J.A., 1994. Coccolithophorid blooms in the global ocean. J. Geophys. Res. 99 (C4), 7467-7482.

Buitenhuis, E., Van Bleijswijk, J., Bakker, D., Veldhuis, M., 1996. Trends in inorganic and organic carbon in a bloom of Emiliania huxleyi in the North Sea. Mar. Ecol. Prog. Ser. 143, 271-282.

Crawford, D.W., Harrison, P.J., 1997. Direct measurement of $\mathrm{pCO}_{2}$ in cultures of marine phytoplankton: how good is the estimate from $\mathrm{pH}_{\mathrm{NBS}}$ and single point titration of alkalinity. Mar. Ecol. Prog. Ser., submitted.

Crawford, D.W., Purdie, D.A., 1997. $\mathrm{pCO}_{2}$ increase in blooms of Emiliania huxleyi: theoretical considerations on the asymmetry between aquisition of $\mathrm{HCO}_{3}^{-}$and respiration of free $\mathrm{CO}_{2}$. Limnol. Oceanogr. 42, 365-372.

Dickson, A.G., 1993. pH buffers for sea water media based on the total hydrogen ion concentration scale. Deep-Sea Res. 40, 107-118.

Dickson, A.G., Goyet, C., 1994. Handbook of Methods for the Analysis of the Various Parameters of the Carbon Dioxide System in Seawater. US Dept. of Energy, ORNL/CDIAC-74.

Egge, J.K., Heimdal, B.R., 1994. Blooms of phytoplankton including Emiliania huxleyi (Haptophyta). Effects of nutrient supply in different N:P ratios. Sarsia 79, 333-348.

Fernández, E., Boyd, P., Holligan, P.M., Harbour, D.S., 1993. Production of organic and inorganic carbon within a large scale coccolithophore bloom in the northeast Atlantic Ocean. Mar. Ecol. Prog. Ser. 97, 271-285.

García-Soto, C., Fernández, E., Pingree, R.D., Harbour, D.S., 1995. Evolution and structure of a shelf coccolithophore bloom in the Western English Channel. J. Plankton Res. 17, 2011-2036.

Harris, R.P., 1994. Zooplankton grazing on the coccolithophore Emiliania huxleyi and its role in inorganic carbon flux. Mar. Biol. 119, 431-439.

Harris, R.P., 1996. Coccolithophorid dynamics: the European Emiliania huxleyi programme EHUX. J. Mar. Syst. 9, 1-11.

Heimdal, B.R., Egge, J.K., Veldhuis, M.J.W., Westbroek, P., 1994. The 1992 Emiliania huxleyi experiment - an overview. Sarsia 79, 285-290.

Holligan, P.M., Harris, R.P., Newell, R.C., Harbour, D.S., Head, R.N., Linley, E.A.S., Lucas, M.I., Tranter, P.R.G., Weekley, C.M., 1984. Vertical distibution and partitioning of organic carbon in mixed, frontal and stratified waters of the English Channel. Mar. Ecol. Prog. Ser. 14, 111-127.

Holligan, P.M., Aarup, T., Groom, S.B., 1989. The North Sea satellite colour atlas. Cont. Shelf Res. 9, 665-765.

Holligan, P.M., Fernández, E., Aiken, J., Balch, W.M., Boyd, P., Burkill, P.H., Finch, M., Groom, S.B., Malin, G., Muller, K., Purdie, D.A., Robinson, C., Trees, C.C., Turner, S.M., Van der Wal, P., 1993a. A biogeochemical study of the coccolithophore, Emiliania huxleyi in the North Atlantic. Glob. Biogeochem. Cycles 7, 870-900.

Holligan, P.M., Groom, S.B., Harbour, D.S., 1993b. What con- 
trols the distribution of the coccolithophorid Emiliania huxleyi in the North Sea? Fish. Oceanogr. 2, 175-183.

Houghton, S.D., 1991. Coccolith sedimentation and transport in the North Sea. Mar. Geol. 99, 267-274.

Kristiansen, S., Paasche, E., 1989. An improved method for determining relative ${ }^{15} \mathrm{~N}$ abundance in ammonium regeneration studies by direct diffusion. Mar. Ecol. Prog. Ser. 54, 203-207.

Kristiansen, S., Thingstad, T.F., Van der Wal, P., Farbrot, T., Skjoldal, E.F., 1994. An Emiliania huxleyi dominated subsurface bloom in Samnangerfjorden, Western Norway. Importance of hydrography and nutrients. Sarsia 79, 357-368.

Marañón, E., González, N., 1997. Primary production, calcification and macromolecular synthesis in a bloom of the coccolithophore Emiliania huxleyi in the North Sea. Mar. Ecol. Prog. Ser. 157, 61-77.

Marañón, E., Fernández, E., Harris, R.P., Harbour, D.S., 1996. Effects of the diatom - Emiliania huxleyi succession on photosynthesis, calcification and carbon metabolism by size-fractionated phytoplankton. Hydrobiologia 317, 189-199.

Matrai, P.A., Keller, M.D., 1993. Dimethylsulphide in a largescale coccolithophore bloom in the Gulf of Maine. Cont. Shelf Res. 13, 831-843.

McCarthy, J.J., 1970. A urease method for urea in seawater. Limnol. Oceanogr. 15, 309-313.

Nimer, N.A., Dixon, G.K., Merret, M.J., 1992. Utilisation of inorganic carbon by the coccolithophorid Emiliania huxleyi (Lohmann) Kamptner. New Phytol. 120, 153-158.

Nejstgaard, J.C., Gismervik, I., Solberg, P.T., 1997. Feeding and reproduction by Calanus finmarchicus, and microzooplankton grazing during mesocosm blooms of diatoms and the coccolithophore Emiliania huxleyi. Mar. Ecol. Prog. Ser. 147, 197217.

Otto, L., Zimmerman, J.T.F., Furnes, G.K., Mork, M., Saetre, R., Becker, G., 1990. Review of the physical oceanography of the North Sea. Neth. J. Sea. Res. 26, 161-238.

Paasche, E., Brubak, S., 1994. Enhanced calcification in the coccolithophorid Emiliania huxleyi (Haptophyceae) under phosphorus limitation. Phycologia 33, 324-330.

Pingree, R.D., Griffiths, D.K., 1982. Tidal friction and the diurnal tides on the North West European Shelf. J. Mar. Biol. Ass. UK 62, 577-593.

Pond, D., Harris, R.P., Head, R.N., Lesley, D.J., 1998. Microplankton species composition and its influence on the lipid composition and fecundity of Calanus finmarchicus in the Northern North Sea. Mar. Ecol. Prog. Ser. (submitted).

Purdie, D.A., Finch, M.S., 1994. Impact of a coccolithophorid on dissolved carbon dioxide in sea water enclosures in a Norwegian fjord. Sarsia 79, 379-387.

Robertson, J.E., Robinson, C., Turner, D.R., Watson, A.J., Boyd, P., Fernández, E., Finch, M., 1994. The impact of a coccolithophore bloom on oceanic carbon uptake in the Northeast
Atlantic during summer 1991. Deep-Sea Res. 41, 297-314.

Saetre, R., Aure, J., Ljøen, R., 1988. Wind effects on the lateral extension of the Norwegian Coastal Water. Cont. Shelf Res. 8, 239-254.

Solórzano, L., 1969. Determination of ammonia in natural waters by the phenolhypochlorite method. Limnol. Oceanogr. 14, 799-801.

Steemann Nielsen, E., 1966. The uptake of free CO2 and $\mathrm{HCO} 3$ - during the photosynthesis of plankton algae with special reference to the coccolithophorid Coccolithus huxleyi. Physiologia Pl. 19, 232-240.

Strickland, J.D.H., Parsons, T.R., 1972. A Practical Handbook of Seawater Analysis. Bull. 167, Fish. Res. Bd Can., Ottawa, 310 pp.

Townsend, D.W., Keller, M.D., Holligan, P.M., Ackleson, S.G., Balch, W.M., 1994. Blooms of the coccolithophore Emiliania huxleyi with respect to hydrography in the Gulf of Maine. Cont. Shelf Res. 14, 979-1000.

Turrell, W.R., Henderson, E.W., Slesser, G., Payne, R., Adams, R.D., 1992. Seasonal changes in the circulation of the northern North Sea. Cont. Shelf Res. 12, 257-286.

Tyrrell, T., Taylor, A.H., 1996. A modelling study of Emiliania huxleyi in the NE Atlantic. J. Mar. Syst. 9, 83-112.

UNESCO, 1968. Zooplankton sampling. Monographs on oceanographic methodology. Unesco, Paris, 174 pp.

Van Bleijswijk, J.D.L., Kempers, R.S., Van der Wal, P., Westbroek, P., Egge, J.K., Lukk, T., 1994. Standing stocks of PIC, POC, PON and Emiliania huxleyi coccospheres and liths in sea water enclosures with different phosphate loadings. Sarsia 79, 307-317.

Van der Wal, P., Kempers, R.S., Veldhuis, M.J.W., 1995. Production and downward flux of organic matter and calcite in a North Sea bloom of the coccolithophore Emiliania huxleyi. Mar. Ecol. Prog. Ser. 126, 247-265.

Westbroek, P., Brown, C.W., Van Bleijswijk, J., Brownlee, C., Brummer, G.J., Conte, M., Egge, J., Fernández, E., Jordan, R., Knappertsbusch, M., Steffels, J., Veldhuis, M., Van der Wal, P., Young, J., 1993. A model system approach to biological climate forcing. The example of Emiliania huxleyi. Global Planet. Change 8, 27-46.

Williams, P.J.LeB., Jenkinson, N.W., 1982. A transportable microprocessor-controlled precise Winkler titration suitable for field station and shipboard use. Limnol. Oceanogr. 27, 576584.

Wolfe, G.V., Steinke, M., Kirst, G.O., 1997. Grazing-activated chemical defence in a unicellular marine alga. Nature 387, 894-897.

Yentsch, C.S., Menzel, D.W., 1963. A method for the determination of phytoplankton chlorophyll and phaeophytin by fluorescence. Deep-Sea Res. 10, 221-231. 